\title{
Prevalence of HBs Ag among blood donors in Transfusion Center, Abidjan (Ivory Coast)
}

\author{
N'guessan N'dri, Amani Sroboua Thot'o, Anassi Jean-Baptiste Okon", Constant Assi, \\ Emile Allah-Kouadio, Dramane Soro, Mamadou Diakité, Amadou Koné, Siaka Koné, \\ Marie Jeanne Lohouès-Kouacou, Benoît-Mathieu Camara
}

Department of Gastroenterology, Faculty of Medical Sciences, Cocody Teaching Hospital Center, Abidjan, Côte d'Ivoire Email: \#okonanassi@yahoo.fr

Received 29 April 2013; revised 3 June 2013; accepted 12 June 2013

Copyright (C) 2013 N'guessan N'dri et al. This is an open access article distributed under the Creative Commons Attribution License, which permits unrestricted use, distribution, and reproduction in any medium, provided the original work is properly cited.

\begin{abstract}
Aim: To study the prevalence of HBsAg among persons without risk factors for hepatitis $B$. Patients and Methods: In a cross-sectional study (28 January to 31 December 2010) about 4310 new volunteer blood donors were consecutively recruited. Among all, a risk factor for hepatitis B was investigated (standardized questionnaire and clinical examination). The blood of all blood donors without risk factors of hepatitis $B$ (n = 3823) was systematically collected for HBsAg, hepatitis $C$ antibody, syphilis serology and human immunodeficiency virus serology. The blood was analyzed with a third generation ELISA (Abbott Murex $\left.^{\circledR}\right)$. Results: HBsAg was positive in 179 persons (4.68\% [95\% CI 4\% - 5\%]). It was associated with hepatitis $C$ antibodies $(0.28 \%(n=11))$, syphilis antibodies $(0.68 \%(n=26))$ or anti-human immunodeficiency virus antibodies $(0.2 \%(\mathrm{n}=8))$. In multivariate analysis, ages from 30 to 39 years $(1.545$ [95\% CI 1.074 to 2.222]), male sex (2.426 [95\% CI 1.550 to 3.799]) and positive syphilis serology (14.344 [95\% CI 5.161 to 39.865]) were associated with the presence of HBsAg. Conclusion: The prevalence of HBsAg among adult without risk factors for hepatitis $B$ is not negligible. Also, it is essential to maintain routine screening before any vaccination against hepatitis $B$ in adult. Our study is not an immunization against hepatitis B only targeting risk populations in adult.
\end{abstract}

Keywords: HBsAg; Prevalence; Risk Factor; Adult; Abidjan

\section{INTRODUCTION}

Hepatitis B virus (HBV) is endemic in Côte d'Ivoire [1].

"No conflict of interest.

\#Corresponding author.
Kra et al. showed in 2001 through a survey conducted by the systematic elimination of blood donors with risk factors for viral hepatitis $\mathrm{B}$, the prevalence of HBs antigen (HBsAg) was $12.5 \%$ in blood donor transfusion center in Bouaké, Côte d'Ivoire [2]. Recently, Assi et al., reported in a study conducted in the general population Abidjanaise with a prevalence of $8 \%$ [3]. This high prevalence of HBsAg was associated with a low rate of HBV vaccinetion coverage, estimated at $2.9 \%$ [3]. Children from 0 - 12 months have been routinely vaccinated since 2001 in Côte d'Ivoire as a part of the expanded program on immunization [4]. According to several authors, catching up vaccination targeted at risk populations is needed to reduce the prevalence of this virus [5]. The aim of our study was to evaluate through the blood donors, the prevalence of HBsAg in Abidjan in people without risk factors etrouvé viral hepatitis $B$ as well as the factors favoring.

\section{MATERIALS AND METHODS}

\subsection{Population}

The blood transfusion center of the Cocody Teaching Hospital Center, one of four university hospitals in Côte d'Ivoire was inaugurated on 28 January 2010. It receives mainly from donors in Abidjan, agglomeration more than 5 million inhabitants.

\subsection{Type of Study, Inclusion and Non-Inclusion}

We have conducted a cross-sectional study of 28 January 2010 to 31 December 2010. All new applicants volunteer blood donation were recruited consecutively and prospectively. They all consistently responded to a standardized questionnaire seeking risk factors for viral hepatitis B: behavior at risk for hepatitis B virus (unprotected sex, multiple sexual partners, using or sharing of unsterilized 
equipment), history of viral hepatitis (B or C) or sexually transmitted diseases, patients with the virus human immunodeficiency virus (HIV), sexually transmitted infection, a history of liver or blood transfusion, sexual partner or around viral hepatitis carrier B, C, HIV and syphilis. They all underwent a clinical examination (clinical abnormalities suggestive of liver disease or HIV or syphilis) and blood hemoglobin. A donor with a risk factor for viral hepatitis B or C, HIV or syphilis, pregnant, nursing, weight $<50 \mathrm{~kg}$ or hemoglobin $<11 \mathrm{~g} / \mathrm{dl}$ was excluded from the study (and donation). All other blood donors were systematically collected for HBsAg, anti heaptitis $\mathrm{C}$ virus (HCV), syphilis serology and HIV status.

\subsection{Serological}

These blood samples were analyzed with an ELISA third generation (combined ELISA Murex ${ }^{\circledR}$ Abbott). When the sample was positive, a second analysis was performed on the same sample with the same ELISA.

\subsection{Statistical Analysis}

Analysis of the results was performed with SPSS * (packing system for social science, Chicago Michigan USA version 17). The seroprevalence of HBsAg was expressed in percentage confidence interval 95\% according to all donors and age, sex, blood group rhesus HIV status vis-à-vis the viral hepatitis $C$, syphilis and human immunodeficiency virus. The relationship between the existence of HBsAg and the factors studied (age, sex, serology hepatitis $C$ virus, human immunodeficiency virus, syphilis and blood groups) has been studied in univariate analysis with Fisher's exact test (quantitative variables) or Chi Square test (qualitative variables). Multivariate analysis was performed by logistic regression. The relationship was significant when the confidence interval of the odds ratio was significantly different from 1 (significance p less than 5\%).

\subsection{Ethics}

All donors were received by a medical center. They were informed of the tests performed, the significance of their positivity. Their consent was obtained before inclusion. They all received advice on all risky practices, the value of vaccination against viral hepatitis B in HIV-negative cases. The assurance was given to them that the data collected is anonymous. All donors received a written invitation to communicate the results of their serological tests. Those carrying markers for syphilis or HIV were assigned systematically to the anti sexually transmitted diseases, the Pasteur Institute of Cocody. Those carriers of HBsAg and/or anti viral hepatitis $C$ are assigned he- patologists University Hospital of Cocody. Subjects not carrying the HBsAg unvaccinated were sensitized to vaccination against hepatitis B. Our study was consistent with the Universal Declaration of Helsinki of 2008.

\section{RESULTS}

We received 4310 blood donors excluded 487 (participation rate $88.7 \%, \mathrm{n}=3823$ ). The age of 3823 blood donors ranged from 17 - 46 years (mean 25.3 years, SD 4.8). There were 1303 women and 2790 men (sex ratio 2.17). Table 1 shows the demographic and serological blood donors HBsAg carriers.

Table 1. Prevalence of HBsAg according to socio demographic and serological characteristics of 3823 persons without risk factors for hepatitis $\mathrm{B}$.

\begin{tabular}{|c|c|}
\hline Factor studied & HBsAg positive $\mathbf{n} / \mathrm{N}(\%)$ \\
\hline \multicolumn{2}{|l|}{ Sex } \\
\hline Male & $156 / 2790(5.6 \%)$ \\
\hline Female & 23/1033 (2.2\%) \\
\hline \multicolumn{2}{|c|}{ Age (years) } \\
\hline $16-19$ & 7/181 (3.9\%) \\
\hline $20-29$ & $126 / 2960(4.3 \%)$ \\
\hline $30-39$ & $42 / 607(6.9 \%)$ \\
\hline $40-49$ & $4 / 75(5.1 \%)$ \\
\hline \multicolumn{2}{|c|}{ Rhesus } \\
\hline Positive & 166/3577 (4.6\%) \\
\hline Negative & $13 / 246(5.3 \%)$ \\
\hline \multicolumn{2}{|l|}{ Blood group } \\
\hline A & $31 / 689(4.5 \%)$ \\
\hline B & 34/918 (3.7\%) \\
\hline $\mathrm{AB}$ & $3 / 115(2.6 \%)$ \\
\hline $\mathrm{O}$ & $111 / 2101(5.3 \%)$ \\
\hline \multicolumn{2}{|c|}{ Viral hepatitis C serology } \\
\hline Positive & 11/127 (8.7\%) \\
\hline Negative & $168 / 3696(4.5 \%)$ \\
\hline \multicolumn{2}{|c|}{ Syphilis serology } \\
\hline Positive & 7/18 (38.9\%) \\
\hline Negative & $172 / 3805$ (4.5\%) \\
\hline \multicolumn{2}{|c|}{ Serology human immunodeficiency virus } \\
\hline Positive & 8/204 (3.9\%) \\
\hline Negative & 171/3619 (4.7\%) \\
\hline
\end{tabular}




\subsection{Prevalence of HbsAg}

HBsAg was positive in 179 donors either 4.68\% [4\% 5\% 95\%] cases. This HBs antigen was associated with hepatitis $\mathrm{C}$ virus antibody, anti syphilis and anti-human immunodeficiency virus respectively $0.28 \%(\mathrm{n}=11)$, $0.68 \%(n=26)$ and $0.2 \%(n=8)$ of the case. No cases of triple infection were found.

\subsection{Risk Factors for the Presence of HbsAg}

In multivariate analysis, only age 30 to 39 years (1.545 [1.074 to 2.222, IC 95\%], $\mathrm{p}=0.007)$, male gender (2.426 [1.550 to 3.799, IC 95\% CI], p < 0.0001) and syphilis serology (14.344 [5.161 to 39.865, IC 95\%], p < 0.0001) were associated (Table 2 ) in the presence of HBsAg.

\section{DISCUSSION}

\subsection{Prevalence of HbsAg}

Our study shows that the prevalence of HBsAg among blood donors without risk factors for viral hepatitis B was $4.76 \%$. This figure is lower than that reported in the blood transfusion center in Bouaké (12.5\%) [2] and recently in the general population in Abidjan (8\%) [3].

The main reason is the systematic elimination of blood donation, all donors with risk factors for hepatitis B in our sample. In the study in Bouaké, blood donors had a history of viral contagion B with $7 \%$ of cases of unprotected intercourse and $2.4 \%$ if more than 2 partners in the last six months [2]. The study Abidjanaise had not sought this history [3]. The demographic structure of our sample was comparable to the two studies cited with a male predominance (sex ratio 2.17) and a mean age of 25 years.

The prevalence of HBsAg in our study was also lower than that reported in the study Matee [6] and several others made in sub-Saharan Africa (Table 3) [7-20]. The difference is, in addition to the elimination of donors with risk factors for hepatitis B virus, the only character voluntary and free blood donation in Côte d'Ivoire. Several authors have shown that voluntary donors were less often compared with HBsAg positive donors paid or replacement donors $[6,12,19,20]$. The existence of risk factors for hepatitis B is associated with a higher prevalence of HBsAg $[6,17]$. However, our figure is in the proportions (2\% - 16\%) reported in West Africa by Tagny et al. [21]. The prevalence of HBsAg in our study was higher than that reported in a recent study in Madagascar [22], the Maghreb [23-25] or in other regions outside Africa $[26,27]$, in connection with low endemicity of HBV in these regions.

This apparent contradiction between the absence of risk factors and B viral detection of HBsAg in blood donors in our study is mainly due to ignorance or forgetfulness of history of viral hepatitis B by respondents.
Table 2. Factors influencing presence of HBsAg in logistic regression.

\begin{tabular}{cccc}
\hline Parameter & OR & [IC95\% OR] & p \\
\hline Male versus female & 2.426 & $1.550-3.799$ & $<0.0001$ \\
HIV $^{\mathrm{a}}$ positive vs negative & 0.584 & $0.265-1.286$ & 0.182 \\
HVC $^{\mathrm{b}}$ positive vs negative & 1.611 & $0.839-3.093$ & 0.240 \\
Syphilis $^{\mathrm{c}}$ positive vs negative & 14.344 & $5.161-39.865$ & $<0.0001$ \\
RHESUS negative vs positive & 0.874 & $0.479-1.597$ & 0.881 \\
30 - 39 years vs. other age & 1.545 & $1.074-2.222$ & 0.007 \\
Blood group O vs other & 1.603 & $0.947-2.729$ & 0.079 \\
\hline
\end{tabular}

${ }^{\mathrm{a}} \mathrm{HIV}=$ human immunodeficiency virus; ${ }^{\mathrm{b}} \mathrm{HCV}=$ hepatitis $\mathrm{C}$ virus; ${ }^{\mathrm{c}} \mathrm{VDRL}$ positive.

Table 3. Prevalence of HBsAg in Africa depending on the country, authors and year of publication.

\begin{tabular}{|c|c|c|}
\hline $\begin{array}{c}\text { Authors and year of } \\
\text { publication }\end{array}$ & Country & HBsAg prevalence \\
\hline Mbanya et al. 2003 [7] & Cameroun & $10.7 \%$ \\
\hline Loua et al. 2005 [8] & Guinea & $14.8 \%$ \\
\hline Dray et al. 2005 [9] & Djibouti & $10.4 \%$ \\
\hline Batina et al. 2007 [10] & Congo & $3 \%$ \\
\hline Buseri et al. 2009 [11] & Nigeria & $18.6 \%$ \\
\hline Diarra et al. 2009 [12] & Mali & $13.9 \%$ \\
\hline Mogtomo et al. 2009 [13] & Cameroun & $16 \%$ \\
\hline Nagalo et al. 2009 [14] & $\begin{array}{l}\text { Burkina } \\
\text { Faso }\end{array}$ & $14.9 \%$ \\
\hline Tounkara et al. 2009 [15] & Mali & $14.9 \%$ \\
\hline Touré-Fall et al. 2009 [16] & Senegal & $9.9 \%$ \\
\hline Adekanle et al. 2010 [17] & Nigeria & $17.1 \%$ \\
\hline Allain et al. 2010 [18] & Ghana & $13 \%$ \\
\hline Stokx et al. 2011 [19] & Mozambique & $10.6 \%$ \\
\hline Dongdem et al. 2012 [20] & Ghana & $11 \%$ \\
\hline
\end{tabular}

Indeed, some patients may reflect a maternal-fetal transmission is a major source of contamination in sub-Saharan Africa [18,28]. Second, given the retrospective nature of the viral contagion Research $\mathrm{B}$, respondents may have forgotten many risk situations experienced B virus. For instance during childhood, intramuscular injections for malaria in childhood with unsterilised material, vaccination chain with reusable devices vaccination before the era of materiovigilance, transfusion for anemia of malaria. Some people can not voluntarily mention unprotected sex, extramarital relationships, addiction. It may also include one or intrafamilial transmission of index cases not knowing his HIV status or viral B. 
The practical consequence is that it is not appropriate to conduct a vaccination against viral hepatitis $B$ without individual serological screening for hepatitis B in a subject not even after a population at high risk for viral hepatitis B (no risk factors found viral B) the risk of vaccinating a subject already carrying HBsAg.

\subsection{Risk Factors for the Presence of HbsAg}

Our study also shows that age and male gender are independent risk factors for viral hepatitis B in people with no history of viral contagion B.

Age is recognized as a risk factor B virus in several studies, however, the age of these studies varied choice. And some like ours the age of 30 years were most at risk $[6,9,18]$. For others it may concerned rather younger subjects (under 30 years) without a clear explanation have been established [11,14,20].

The male is a recognized independent risk factor for carriage of HBsAg in individuals with or without risk factors for viral B $[6,14,24]$.

Subjects without risk factors found HVB with positive syphilis serology had significantly more (odds ratio 14) co infection HBV. This is a common condition in black Africa and sharing sexual transmission, blood and vertically with the hepatitis B [6]. This association was also found among blood donors in Tanzania [6] and Nigeria [11].

The blood group is not a risk factor for carriage of HBsAg in our study although lower in the blood group B and higher in blood group O. This difference was also observed in other studies correlated with the proportion of blood groups in the populations studied. However, none has demonstrated a link between blood groups and viral hepatitis B or C $[23,29,30]$.

\section{CONCLUSIONS}

The prevalence of HBsAg (4.76\%) among those without risk factors for hepatitis B virus found although lower than that reported in the population in Abidjan, was not negligible.

Because of the prevalence, our study provides no argument for vaccination policy based solely on at-risk B virus populations in our endemic area viral $\mathrm{B}$. It is essential to detect individual viral hepatitis B before vaccination against viral hepatitis $B$ in adults.

\section{REFERENCES}

[1] Rouet, F., Chaix, M.L., Inwoley, A., Msellati, P., Viho, I., Combe, P., et al. (2004) HBV and HCV prevalence and viraemia in HIV-positive and HIV-negative pregnant women in Abidjan, Côte-d'Ivoire: The ANRS 1236 study. Journal of Medical Virologie, 74, 34-40. doi:10.1002/jmv.20143
[2] Kra, O., N’Dri, N., Ehui, E., Ouattara, B. and Bissagnene, E. (2007) Prevalence of HBsAg among blood donors in regional blood transfusion center in Bouaké (Côte d'Ivoire) in 2001. Bulletin de la Société de Pathologie Exotique, 100, 127-129.

[3] Assi, C., Allah-Kouadio, E., Ouattara, A., Diakité, M., Koné, S., Lohouès-Kouacou, M.J., et al. (2011) Vaccination coverage against the hepatitis $\mathrm{B}$ and prevalence of HBsAg: Cross-sectional study of 592 persons in Abidjan. Clinics and Research in Hepatology and Gastroenterology, 35, 506-507. doi:10.1016/j.clinre.2011.02.010

[4] Magoni, M., Ekra, K.D., Aka, L.N., Sita, K.S. and Kanga, K. (2009) Effectiveness of hepatitis-B vaccination in Ivory Coast: The case of the Grand-Bassam health district. Annals of Tropical Medicine and Parasitology, 103, 519527. doi:10.1179/136485909X451816

[5] Poland, G.A. and Jacobson, R.M. (2004) Clinical practice: Prevention of hepatitis B with the hepatitis B Vaccine. New England Journal of Medicine, 351, 2832-2838. doi:10.1056/NEJMcp041507

[6] Matee, M.I.N., Magesa, P.M. and Lyamuya, E.F. (2006) Seroprevalence of human immunodeficiency virus, hepatitis $\mathrm{B}$ and $\mathrm{C}$ viruses and syphilis infections among blood donors at the Muhimbili National Hospital in Dar Es Salaam, Tanzania. Biomedical Central Public Health, 6, 21-26. doi:10.1186/1471-2458-6-21

[7] Mbanya, D.N., Takam, D. and Ndumbe, P.M. (2003) Serological findings amongst first-time blood donors in Yaoundé, Cameroon: Is safe donation a reality or a myth? Transfusion Medicine, 13, 267-273. doi:10.1046/j.1365-3148.2003.00453.x

[8] Loua, A., Diallo, M.B., Agassouba, F.B.M., Camara, M., Bah, M.A. and Cisse, A. (2005) Seroprevalence of heaptitis B among blood donors in Guinea. Médecine Tropicale, 65, 396-397.

[9] Dray, X., Dray-Spira, R., Bronstein, J.A. and Mattera, D. (2005) [Prevalences of HIV, hepatitis B and hepatitis C in blood donors in the Republic of Djibouti]. Médecine Tropicale, 65, 39-42.

[10] Batina, A., Kabemba, S. and Malengela, R. (2007) Infectious markers among blood donors in Democratic Republic of Congo (DRC). Revue Médicale de Bruxelle, 28, 145-149.

[11] Buseri, F.I., Muhibi, M.A. and Jeremiah, Z.A. (2009) Seroepidemiology of transfusion-transmissible infectious diseases among blood donors in Osogbo, south-west Nigeria. Blood Transfusion, 7, 293-299.

[12] Diarra, A., Kouriba, B., Baby, M., Murphy, E. and Lefrere, J.J. (2009) HIV, HCV, HBV and syphilis rate of positive donations among blood donations in Mali: Lower rates among volunteer blood donors. Transfusion Clinique et Biologique, 16, 444-447. doi:10.1016/j.tracli.2009.09.004

[13] Mogtomo, M.L., Fomekong, S.L., Kuate, H.F. and Ngane, A.N. (2009) Screening of infectious microorganisms in blood banks in Douala (1995-2004). Santé, 19, 3-8.

[14] Nagalo, M.B., Sanou, M., Bisseye, C., Kaboré, M.I., Nebie, Y.K., Kienou, K., et al. (2011) Seroprevalence of human immunodeficiency virus, hepatitis B and $C$ viruses and syphilis among blood donors in Koudougou (Burkina 
Faso) in 2009. Blood Transfusion, 9, 419-424.

[15] Tounkara, A., Sarro, Y.S., Kristensen, S., Dao, S., Diallo, H., Diarra, B., et al. (2009) Seroprevalence of HIV/HBV coinfection in Malian blood donors. Journal of the International Association of Physicians in AIDS Care (Chic), 8, 47-51. doi:10.1177/1545109708330118

[16] Touré-Fall, A.O., Dièye, T.N., Sall, A., Diop, M., Seck, M., Diop, S., et al. (2009) Residual risk of transmission of HIV and HBV, in Senegalese national blood bank from 2003 to 2005. Transfusion Clinique et Biologique, 16, 439-443. doi:10.1016/j.tracli.2009.09.005

[17] Adekanle, O., Ndububa, D.A., Ayodeji, O.O., Paul-Odo, B. and Folorunso, T.A. (2010) Sexual transmission of the hepatitis B virus among blood donors in a tertiary hospital in Nigeria. Singapore Medical Journal, 51, 944-947.

[18] Allain, J.P., Candotti, D., Soldan, K., Sarkodie, F., Phelps, B., Giachetti, C., Shyamala, V., et al. (2003) The risk of hepatitis B virus infection by transfusion in Kumasi, Ghana. Blood, 101, 2419-2425. doi:10.1182/blood-2002-04-1084

[19] Stokx, J., Gillet, P., De Weggheleire, A., Casas, E.C., Maendaenda, R., Beulane, A.J., et al. (2011) Seroprevalence of transfusion-transmissible infections and evaluation of the pre-donation screening performance at the Provincial Hospital of Tete, Mozambique. BMC Infectious Diseases, 23, 111-141.

[20] Dongdem, J.T., Kampo, S., Soyiri, I.N., Asebga, P.N. and Ziem, J.B. (2012) Prevalence of hepatitis B virus infection among blood donors at the Tamale Teaching Hospital, Ghana (2009). BMC Research Notes, 5, 115-126. doi:10.1186/1756-0500-5-115

[21] Tagny, C.T., Diarra, A., Yahaya, R., Hakizimana, M., Nguessan, A., Mbensa, G., et al. (2009) Characteristics of blood donors and donated blood in sub-Saharan Francophone Africa. Transfusion, 49, 1592-1599. doi:10.1111/j.1537-2995.2009.02137.x

[22] Arivelo, R.Z., Hendrison, R.D., Elie, R.M.F., Tantely, R.M., Ramamonjisoa, A., Barnia, R.F., et al. (2011) The seroprevalence of hepatitis B surface antigen among first time blood donors in Antananarivo (Madagascar) from 2003 to 2009. Blood Transfusion, 9, 475-477.
[23] Eissa, S.A., Abdel Meguid, L.M., Ebeid, S.M., Abou Elfetouh, R.M. and Abdel Moneim, G.M. (2007) National Cancer Institute Experience in Healthy Egyptian Blood Donors as Regards Blood Group Frequencies and Seroprevalence of Hepatitis B Virus, Hepatitis C Virus \& HIV: 10 Year Evaluation. Journal of the Egyptian National Cancer Institute, 19, 71-76.

[24] Wasfi, O.A. and Sadek, N.A. (2011) Prevalence of heaptitis B surface antigen and hepatitis $C$ virus antibodies among blood donors in Alexandria, Egypt. Eastern Mediterranean Health Journal, 17, 238-242.

[25] Zohoun, A., Hadef, R., Zahid, H. and Benkirane, M. (2011) Seroprevalence of HBV and HCV in blood donors at the Blood Transfusion Center of Mohammed V Military Teaching Hospital in Rabat Morocco. Medecine Tropicale, 71, 513-514.

[26] Meena, M., Jindal, T. and Hazarika, A. (2011) Prevalence of hepatitis $\mathrm{B}$ virus and hepatitis $\mathrm{C}$ virus among blood donors at a tertiary care hospital in India: A five-year study. Transfusion, 51, 198-202. doi:10.1111/j.1537-2995.2010.02801.x

[27] O’Brien, S.F., Xi, G., Fan, W., Yi, Q.L., Fearon, M.A., Scalia, V. and Goldman, M. (2008) Epidemiology of hepatictis B in Canadian blood donors. Transfusion, 48, 23232330. doi:10.1111/j.1537-2995.2008.01845.x

[28] Lohouès-Kouacou, M.J., Touré, M., Hillah, J., Camara, B.M., Ndri, N., Kouamé, K.J., et al. (1998) Materno-foetal transmission of hepatitis B virus in Ivory Coast. Plea for mass vaccination. Santé, 8, 401-404.

[29] Jeremiah, Z.A., Koate, B., Buseri, F. and Emelike, F. (2008) Prevalence of antibodies to hepatitis $C$ virus in apparently healthy Port Harcourt blood donors and association with blood groups and other risk indicators. Blood Transfusion, 6, 150-155.

[30] Umolu, P.I., Okoror, L.E. and Orhue, P. (2005) Human immunodeficiency virus (HIV) seropositivity and hepatictis B surface antigenemia (HBSAG) among blood donors in Benin City, Edo state, Nigeria. African Health Sciences, 5, 55-58. 